\title{
ANALISA KEMAMPUAN KEUANGAN PADA KETIGA DAERAH TINGKAT II DI JAWA TENGAH DALAM MENJALANKAN OTONOMI DAERAH
}

\author{
Oleh: Ayu Noviani Hanum, SE, Akt \\ Fakultas Ekonomi \\ Universitas Muhammadiyah Semarang
}

\begin{abstract}
Abstrak:
Otonomi Daerah adalah kewenangan daerah otonom untuk mengatur dan mengurus kepentingan masyarakat setempat menurut prakarsa sendiri berdasarkan aspirasi masyarakat, sesuai dengan peraturan perundang-undangan. Keputusan politik pemberlakuan Otonomi Daerah di Indonesia dimulai sejak tanggal 1 Januari 2001. Tujuan otonomi daerah bagi daerah adalah untuk mewujudkan political equality, local accountability dan local responsiveness.

Untuk mengukur kemandirian keuangan daerah, dapat menggunakan tiga tolak ukur, yaitu : (1) Kemampuan daerah untuk memenuhi kebutuhannya sendiri, (2) Efektifitas dan efisiensi pengeluaran anggaran daerah dan (3) Derajat Desentralisasi Fiskal (DDF).

Dari tiga daerah kabupaten yang diteliti, yaitu Kabupaten Klaten, Pati dan Pemalang dapat di peroleh kesimpulan untuk tolak ukur pertama, bahwa ketiga kabupaten memiliki kesenjangan fiskal yang negatif selama periode 2001-2004, dengan rata-rata kesenjangan fiskal untuk Kabupaten Klaten sebesar -30,5444, Kabupaten Pati sebesar -62,3171 dan Kabupaten Pemalang sebesar -71,3171, ini berarti bahwa ketiga daerah kabupaten belum mampu memenuhi kebutuhan daerahnya.

Untuk tolak ukur kedua, hasil analisis menunjukkan bahwa sektor basis di Klaten hanya memperoleh proporsi total rata-rata sebesar $27,65 \%$ dan $72,35 \%$ untuk sektor nonbasis. Untuk Pati, sektor basis hanya memperoleh proporsi total rata-rata sebesar $37,01 \%$ dan 62,99\% untuk sektor nonbasis. Sedangkan untuk Pemalang, sektor basis hanya memperoleh proporsi total rata-rata sebesar 5,65\% dan 94,34\% untuk sektor nonbasis.

Untuk tolak ukur terakhir, yaitu DDF, hasil analisis data menunjukkan rasio-rasio DDF ketiga kabupaten masih jauh berada di angka satu (1). Rasio DDF yang pertama, yaitu perbandingan rata-rata antara PAD dengan total penerimaan daerah untuk Klaten sebesar 4,49\%, Pati sebesar 9,80\%, dan Pemalang sebesar 6,69\%. (2) Rasio DDF yang kedua, yaitu rata-rata perbandingan antara PAD ditambah BHPNP terhadap total pengeluaran daerah juga sangat rendah, untuk Klaten sebesar 9,11\%, Pati sebesar 18,06\%, dan Pemalang sebesar $12,62 \%$. Hal ini menunjukkan bahwa kemampuan keuangan pemerintah daerah Klaten, Pati dan Pemalang dalam membiayai urusan daerah dengan sumber keuangan sendiri masih sangat rendah. Akibatnya ketergantungan terhadap pemerintah pusat semakin tinggi.

Dengan tidak terpenuhinya ketiga tolak ukur yang diterapkan pada pemerintah Kabupaten Klaten, Pati dan Pemalang terhadap standar kemampuan keuangan daerah dalam menghadapi otonomi daerah, dapat ditarik kesimpulan bahwa pemerintah Kabupaten Klaten, Pati dan Pemalang belum mampu atau belum layak dalam melaksanakan otonomi daerah dari sektor keuangan.
\end{abstract}

Kata Kunci : Otonomi Daerah, kesenjangan fiskal, sektor basis, DDF. 


\section{PENDAHULUAN}

Sejak era pembangunan ber-Pelita mulai tahun 1969 propinsi Jawa Tengah "terjepit" di antara 2 propinsi besar Jawa Barat, DKI Jakarta dan Jawa Timur, yang keduanya "maju pesat" melalui industrialisasi yang bepusat di "Jabotabek" dan Surabaya. Memang benar Jawa Tengah memperoleh "pelimpahan kemakmuran" (trickle down) dari kemajuan propinsi-propinsi tetangganya ini, tetapi pada saat yang sama juga menerima dampak negatif, karena menjadi pemasok tenaga murah yang hanya dinikmati mereka yang meninggalkan desanya. Menurut data yang di peroleh dari BKKBN, pada akhir tahun 1999, jika tingkat kemiskinan di Jawa Tengah di bagi tiga; kemiskinan tinggi, sedang dan rendah, maka pada tahun 1999, 3 besar kabupaten termiskin adalah Klaten (46,21\%), Pemalang $(44,37 \%)$ dan Pati $(43,79 \%)$.

Keputusan politik pemberlakuan Otonomi Daerah yang dimulai sejak tanggal 1 Januari 2001, telah membawa implikasi yang luas dan serius. Otonomi Daerah merupakan fenomena politis yang menjadikan penyelenggaraan pemerintah yang sentralistik birokratis ke arah desentralistik parsipatoris. UndangUndang no.25 tahun 1999 tentang Perimbangan Keuangan antara Pemerintah Pusat dan Pemerintah Daerah, telah melahirkan paradigma baru dalam pelaksanaan otonomi Daerah, yang meletakkan otonomi penuh, luas dan bertanggungjawab pada daerah kabupaten dan kota.

$$
\text { Konsekuensi logis }
$$

pelaksanaan otonomi daerah Berdasarkan UU No.22 tahun 1999 dan UU No.25 tahun 1999 menyebabkan perubahan dalam Manajemen keuangan daerah. Perubahan tersebut antara lain adalah perlu dilakukannya budgeting reform atau reformasi anggaran. Reformasi anggaran ini meliputi proses penyusunan, pengesahan, pelaksanaan dan pertanggungjawaban anggaran.
Aspek utama budgeting reform adalah perubahan dari traditional budget ke performance budget. Secara garis besar terdapat dua pendekatan utama yang memiliki perbedaan mendasar. Kedua pendekatan itu adalah : (a) Anggaran tradisional atau anggaran konvensional; dan (b) Pendekatan baru yang sudah dikenal dengan nama pendekatan New Public Management.

Salah satu syarat yang diperlukan dalam era otonomi daerah adalah tersedianya sumber-sumber pembiayaan. Sumber-sumber pembiayaan tersebut telah diatur dengan UU No.25 tahun 1999 tentang perimbangan keuangan antara pemerintah pusat dan pemerintah daerah. Di samping sumber pembiayaan dari luar atau pemerintah pusat, pemerintah kabupaten juga mempunyai sumber pembiayaan dari dalam diri sendiri atau yang kita kenal dengan Pendapatan Asli Daerah (PAD)

\section{PERUMUSAN MASALAH}

Bagaimanakah kemampuan keuangan Pemerintah kabupaten Pemalang, Pekalongan dan Pati dalam memenuhi kebutuhan publik serta pengelolaan daerah secara efektif dan efisien, Berdasarkan pada anggaran penerimaan dan pengeluaran?

\section{TUJUAN}

Tujuan dari penelitian ini adalah untuk :

a. Mengetahui apakah dari segi keuangan Pemerintah Kabupaten Klaten, Pati dan Pemalang telah mampu memenuhi kebutuhan daerahnya secara mandiri.

b. Mengetahui pengelolaan keuangan pada sektor unggulan, apakah alokasinya sudah tepat, efektif dan efisien sehingga mampu meningkatkan kemampuan keuangan Pemerintah Kabupaten Klaten, Pemalang dan Pati.

c. Mengetahui optimalisasi Pendapatan Asli Daerah (PAD) dan bagi hasil Pemerintah Kabupaten 
Klaten, Pati dan Pemalang sebagai sumber kemandirian.

\section{PEMBAHASAN}

\section{Landasan Otonomi Daerah}

Otonomi daerah dilaksanakan dalam kerangka Negara Kesatuan Republik Indonesia sebagai perwujudan sistem penyelenggaraan pemerintahan yang berdasar asas desentralisasi yang diwujudkan dengan otonomi yang luas, nyata dan bertanggung jawab yang telah diatur kerangka landasannya dalam Undang-Undang Dasar 1945

Dalam sisi sejarah perkembangan penyelenggaraan pemerintahan di daerah dalam merealisasikan amanat konstitusi telah dikeluarkan berbagai peraturan perundang-undangan, antara lain :

a. Undang-undang No.1 Tahun 1945

b. Undang-undang No.1 Tahun 1957

c. Undang-undang No.22 Tahun 1958

d. Undang-undang No.18 tahun 1965

e. Undang-undang No.5 Tahun 1974

f. Undang-undang No.22 Tahun 1999

g. Undang-Undang No.25 Tahun 1999

h. Undang-Undang No.17 Tahun 2003

i. Undang-Undang No.32 Tahun 2004

j. Undang-Undang No.33 Tahun 2004

\section{Tujuan Otonomi Daerah}

Tujuan otonomi daerah menurut Smith (1985) dalam analisa CSIS yang dikemukakan oleh Syarif Hidayat, dibedakan dari dua sisi kepentingan, yaitu kepentingan pemerintah Pusat dan pemerintah Daerah. Dari kepentingan Pemerintah Pusat, tujuan utamanya adalah pendidikan politik, pelatihan kepemimpinan, menciptakan stabilitas politik dan mewujudkan demokratisasi siste, pemerintahan di daerah. Sementara, bila dilihat dari kepentingan Pemerintah Daerah, ada tiga tujuan, yaitu (Abdul Halim, 2001:23) (1)Untuk mewujudkan apa yang disebut political equality, (2) untuk mewujudkan local accountability dan (3) Untuk mewujudkan local responsiveness.

\section{Faktor Penunjang Otonomi Daerah}

Faktor yang mempengaruhi dalam pelaksanaan otonomi daerah, antara lain (Josef Riwu, 1997: 60) :

a. SDM yang baik

b. Keuangan harus cukup dan baik

c. Peralatannya harus cukup dan baik

d. Organisasi dan manajemen yang baik

Faktor manusia sebagai pelaksana otonomi yang harus baik adalah hal daerah. yang sangat penting, karena merupakan subyek dari otonomi daerah. Keuangan yang cukup baik merupakan tulang punggung dari seluruh aktivitas kegiatan kepemerintahan dan dengan keadaan keuangan yang baik maka dapat membuat stabilnya suatu pemerintahan dan juga sebaliknya. Tersedianya peralatan yang cukup dan baik, akan dapat memperlancar kegiatan pemerintahan secara teknis, sedangkan keadaan organisasi dan manajemen yang baik, dapat membuat kondisi pemerintahan itu sehat serta mengutamakan keefektifan dan keefisienan.

\section{METODE PENELITIAN}

Tolak Ukur Kemampuan Keuangan Daerah

Dalam mengukur dan menganalisa kemampuan keuangan suatu daerah di era otonomi, maka peneliti mengembangkan metode analisa kuantitatif yang didasarkan atas landasan hukum otonomi daerah (UU No.22 dan UU No.25 tahun 1999) dengn tiga tolak ukur. Ketiga tolak ukur tersebut,yaitu ; Penelitian untuk menilai kemampuan keuangan daerah dalam melaksanakan otonomi daerah dibagi menjadi tiga ketegori, yaitu :

(1) Kemampuan keuangan daerah untuk memenuhi kebutuhan daerah, diukur dengan menggunakan kapasitas fiskal dan kebutuhan fiskal untuk mengetahui 
apakah kapasitas suatu daerah sudah mampu memenuhi kebutuhannya.

(2) Efektifitas dan Efisiensi pengeluaran anggaran daerah, dengan menggunakan model Location Quatient ( $L Q)$ dan perbandingan perbandingan untuk mengukur apakah pengeluaran daerah yang terjadi sudah tepat pada alokasi di sektor basis.

(3) Kemampuan keuangan dalam membiayai urusan daerahnya melalui sumber keuangan daerahnya sendiri dengan menggunakan analisa pertumbuhan, perhitungan rasio-rasio dan perhitungan Derajat Desentralisasi Fiskal (DDF)

\section{Kebutuhan Fiskal, Kapasitas Fiskal dan Kesenjangan Fiskal}

Kebutuhan fiskal Fiskal (fiscal need) diasumsikan sebagai kebutuhan yang terbagi atas dua macam kebutuhan, yaitu kebutuhan aparatur dan kebutuhan publik atau sering disebut juga kebutuhan daerah.
Usaha untuk memenuhi kebutuhan daerah tidak terlepas dari kemampuan menggalang sumber-sumber keuangan (fiscal resource). Sumber keuangan ini diperoleh dari berbagai unsur, seperti dari potensi sumber daya yang ada di daerah yang nantinya digunakan untuk memenuhi kebutuhan fiskal daerah itu. Kemampuan untuk menggalang sumber-sumber keuangan untuk memenuhi kebutuhan fiskal disebut kapasitas fiskal (fiscal capacity)

Kesenjangan fiskal (fiscal gap) adalah selisih yang terjadi antara kapasitas fiskal dan kebutuhan fiskal. Bila kesenjangan fiskal menunjukkan hasil yang positip, maka kapasitas fiskal dari daerah tersebut mampu memenuhi kebutuhan fiskal yang diharapkan daerah tersebut dan menunjukkan bahwa kemampuan keuangan didaerah tersebut baik. Rumusnya yaitu (Abdul Halim, 2001:325-32

KAPASITAS FISKAL (FC)

FC $=\frac{\text { Rata-rata PDRB Kabupaten per Kapita }}{\text { FCs }}$

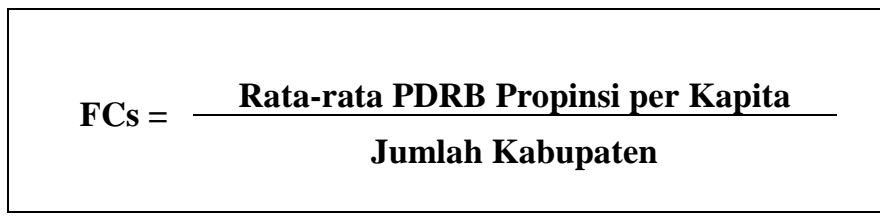

Keterangan: FC = Kapasitas Fiskal

FCs = Kapasitas Fiskal Standar 


\section{KEBUTUHAN FISKAL}

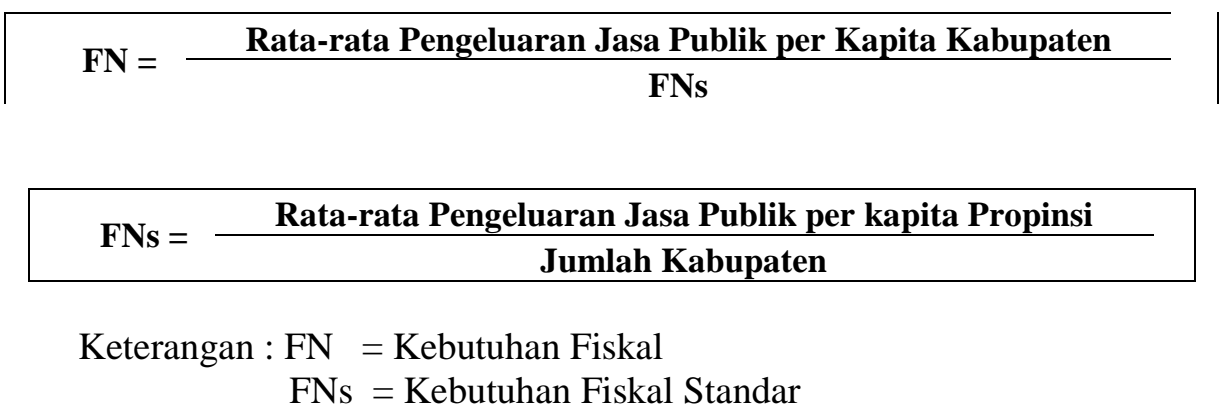

\section{Model LQ}

Untuk mengetahui suatu sektor merupakan sektor basis atau bukan digunakan model Location Quatient (LQ) dengan formula (Lincoln Arsyad: 1998)

$$
L Q=\frac{v i / v t}{V i / V t}
$$

Keterangan : $\quad$ vi $\quad$ pendapatan sektor i di suatu daerah kabupaten

$\mathrm{v} \mathrm{t}=$ pendapatan total suatu daerah kabupaten

$\mathrm{Vi}=$ Pendapatan sektor i di propinsi

$\mathrm{Vt}=$ Pendapatan total di propinsi

Semakin tinggi nilai LQ, semakin tinggi keunggulan komparatif bagi daerah untuk mengembangkan sektor basisnya. Ketentuan bila LQ > 1 maka menunjukkan bahwa sektor tersebut tergolong sektor basis, artinya prospektir untuk dikembangkan. Sedangkan sebaliknya bila LQ $<1$, maka sektor tersebut kurang prospektif untuk dikembangkan (Lincoln Arsyad , 1998).

\section{Derajat Desentralisasi Fiskal (DDF)}

Derajat Desentralisasi Fiskal adalah tingkat kemampuan pemerintah daerah dalam memanfaatkan, mengelola dan meningkatkan penerimaan daerah secara mandiri untuk membiayai sistem pemerintahannya yang masih tersentralisasi baik secara administrasi dan pemanfaatannya diatur atau dilakukan oleh pemerintah pusat.

Langkah-langkah penelitiannya adalah sebagai berikut :

a. Menghitung pertumbuhan PAD selama periode penelitian

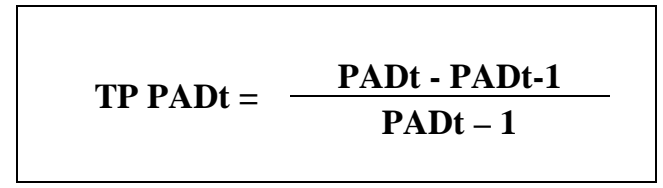

Keterangan : TP PADt $=$ Tingkat pertumbuhan PAD tahun berjalan

PADt = PAD tahun berjalan

PADt-1 = PAD tahun sebelumnya

\section{b. Menghitung Derajat Desentralisasi Fiskal (DDF)}

b.1. DDF1 adalah rasio perbandingan antara PAD dengan TPD (Kuncoro, 1995:8) 


$$
\mathrm{DDF} 1=\frac{\mathrm{PADt}}{\mathrm{TPDt}} \times \quad 100 \%
$$

Keterangan : DDF1 = Derajat Desentralisasi Fiskal

PADt $=$ Total PAD tahun $\mathrm{t}$

TPDt $=$ Total Penerimaan Daerah tahun $\mathrm{t}$

b.2. DDF2 adalah seberapa besar kemampuan keuangan daerah dalam menghadapi otonomi daerah, jika pengeluarannya dibiayai dari PAD dan Bag i Hasil (LPEM FE-UI:2000)

$$
\mathrm{DDF} 2=\frac{(\mathrm{PAD}+\mathrm{Bagi} \text { Hasil })}{\mathrm{PTt}} \times \quad 100 \%
$$

Keterangan :

$(\mathrm{PAD}+$ Bagi hasil $) \mathrm{t}=$ jumlah PAD + Bagi Hasil thn $\mathrm{t}$

PTt $\quad=$ Pengeluaran total tahun $\mathrm{t}$

HASIL ANALISIS DATA

Tolak Ukur Pertama (Kemampuan Keuangan kabupaten dalam memenuhi Kebutuhan Daerah)

Tabel 1.Kapasitas dan Kebutuhan Fiskal kabupaten Klaten

\begin{tabular}{|c|c|c|c|c|}
\hline Tahun & Kapasitas & Kebutuhan & Kesenjangan & Tanda \\
\hline 1 & 27.7517 & 64.4594 & $(36.7078)$ & Negatif \\
\hline 2 & 31.2253 & 44.9097 & $(13.6843)$ & Negatif \\
\hline 3 & 33.4244 & 93.7818 & $(60.3574)$ & Negatif \\
\hline 4 & 35.6736 & 47.1016 & $(11.4280)$ & Negatif \\
\hline
\end{tabular}

Tabel 2. Kapasitas dan Kebutuhan Fiskal Kabupaten Pati

\begin{tabular}{|c|r|r|r|l|}
\hline Tahun & Kapasitas & Kebutuhan & Kesenjangan & \multicolumn{1}{|c|}{ Tanda } \\
\hline 1 & 24.3551 & 120.1977 & $(95.8426)$ & Negatif \\
\hline 2 & 25.8831 & 84.4119 & $(58.5288)$ & Negatif \\
\hline 3 & 25.4408 & 125.3033 & $(99.8626)$ & Negatif \\
\hline 4 & 25.2636 & 20.2981 & 4.9655 & Positif \\
\hline
\end{tabular}

Tabel 3. Kapasitas dan Kebutuhan Fiskal Kabupaten Pemalang

\begin{tabular}{|c|r|r|r|l|}
\hline Tahun & Kapasitas & Kebutuhan & Kesenjangan & Tanda \\
\hline 1 & 17.2126 & 136.5380 & $(119.33)$ & Negatif \\
\hline 2 & 16.5937 & 72.4553 & $(55.86)$ & Negatif \\
\hline 3 & 16.8603 & 102.8143 & $(85.95)$ & Negatif \\
\hline 4 & 16.5864 & 42.0893 & $(25.50)$ & Negatif \\
\hline
\end{tabular}


Dari tiga daerah kabupaten yang diteliti, yaitu Klaten, Pati dan Pemalang dapat di peroleh kesimpulan untuk tolak ukur pertama, bahwa ketiga kabupaten memiliki kesenjangan fiskal yang negatif selama tahun pertama sampai dengan keempat setelah penerapan otonomi daerah, dengan rata-rata kesenjangan fiskal untuk Kabupaten Klaten sebesar -30,5444, Kabupaten Pati sebesar -62,3171 dan Kabupaten Pemalang sebesar -71,3171, ini berarti bahwa ketiga daerah kabupaten belum mampu memenuhi kebutuhan daerahnya.

\section{Tolak Ukur Kedua ( Efektifitas dan Efisiensi Pengeluaran Daerah}

Untuk tolak ukur kedua, hasil analisis menunjukkan bahwa sektor basisTol di Klaten hanya memperoleh proporsi total rata-rata sebesar $27,65 \%$ dan $72,35 \%$ untuk sektor nonbasis. Untuk Pati, sektor basis hanya memperoleh proporsi total rata-rata sebesar $37,01 \%$ dan $62,99 \%$ untuk sektor nonbasis. Sedangkan untuk Pemalang, sektor basis hanya memperoleh proporsi total rata-rata sebesar 5,65\% dan 94,34\% untuk sektor nonbasis.

Dapat ditarik kesimpulan bahwa dari tahun pertama sampai dengan keempat setelah penerapan otonomi daerah, pengeluaran pada sektor basis lebih sedikit daripada pengeluaran pada sektor nonbasis. Seharusnya pengeluaran terbesar ditujukan pada sektor-sektor yang memiliki potensi.

\section{Tolak Ukur Ketiga (Derajat Desentralisasi Fiskal) \\ a. Pertumbuhan PAD dan Bagi Hasil}

Tingkat pertumbuhan PAD dan BHPNP Kabupaten Klaten, Pati dan Pemalang, dapat diketahui dari tabel berikut

Tabel 4. Pertumbuhan PAD dan BHPNP Kabupaten Klaten

\begin{tabular}{|c|c|c|}
\hline Tahun & $\begin{array}{c}\text { PAD } \\
(\boldsymbol{\%})\end{array}$ & $\begin{array}{c}\text { BHPNP } \\
(\boldsymbol{\%})\end{array}$ \\
\hline 1 & $120.59 \%$ & $42.98 \%$ \\
\hline 2 & $17.89 \%$ & $21.18 \%$ \\
\hline 3 & $27.83 \%$ & $57.24 \%$ \\
\hline
\end{tabular}

\begin{tabular}{|c|c|c|}
\hline 4 & $21.93 \%$ & $25.78 \%$ \\
\hline Rata-rata & $\mathbf{4 7 . 0 6 \%}$ & $\mathbf{3 6 . 8 0 \%}$ \\
\hline
\end{tabular}

Tabel 5.Pertumbuhan PAD \& BHPNP Kab.Pati

\begin{tabular}{|c|r|r|}
\hline Tahun & PAD(\%) & BHPNP(\%) \\
\hline 1 & 96.52 & 117.32 \\
\hline 2 & 38.17 & 5.09 \\
\hline 3 & 17.65 & 96.73 \\
\hline 4 & 35.49 & $(49.24)$ \\
\hline Rata-rata & $\mathbf{4 6 . 9 6}$ & $\mathbf{4 2 . 4 7}$ \\
\hline
\end{tabular}

Tabel 6 . Pertumbuhan PAD \& BHPNP Kab. Pemalang

\begin{tabular}{|c|c|r|}
\hline Tahun & $\begin{array}{l}\text { PAD } \\
(\boldsymbol{\%})\end{array}$ & $\begin{array}{l}\text { BHPNP } \\
(\boldsymbol{\%})\end{array}$ \\
\hline 1 & 175.95 & 22.18 \\
\hline 2 & 28.53 & 47.08 \\
\hline 3 & 9.66 & 43.52 \\
\hline 4 & $(10.88)$ & 8.67 \\
\hline Rata-rata & $\mathbf{5 0 . 8 1}$ & $\mathbf{3 0 . 3 6}$ \\
\hline
\end{tabular}

b.Menghitung DDF 1 dengan membandingkan Rasio-rasio antara PAD, BHPNP dan Sumbangan Pusat terhadap Penerimaan Daerah

Tabel 7. Rasio PAD, BHPNP

\& Sumbangan Pusat Kab.Klaten

\begin{tabular}{|c|c|c|c|}
\hline Tahun & PAD (\%) & BHNP & $\begin{array}{c}\text { Sumbangan } \\
\text { Pusat }\end{array}$ \\
\hline 1 & 4.66 & 3.16 & 92.2 \\
\hline 2 & 4.10 & 2.99 & 81.07 \\
\hline 3 & 4.15 & 3.73 & 81.94 \\
\hline 4 & 5.25 & 4.86 & 80.61 \\
\hline Rata-rata & $\mathbf{4 . 4 9}$ & $\mathbf{3 . 6 8}$ & $\mathbf{8 4 . 4 6}$ \\
\hline
\end{tabular}

Tabel 8. Rasio PAD, BHPNP

\& Sumbangan Pusat Kab.Pati

\begin{tabular}{|c|c|c|c|}
\hline Tahun & PAD (\%) & BHNP & $\begin{array}{c}\text { Sumbangan } \\
\text { Pusat }\end{array}$ \\
\hline 1 & 8.22 & 7.12 & 89.15 \\
\hline 2 & 9.49 & 6.25 & 84.36 \\
\hline 3 & 8.89 & 9.79 & 82.31 \\
\hline 4 & 12.61 & 5.21 & 83.03 \\
\hline Rata-rata & $\mathbf{9 . 8 0}$ & $\mathbf{7 . 0 9}$ & $\mathbf{8 4 . 7 1}$ \\
\hline
\end{tabular}

Tabel 9. Rasio PAD, BHPNP

\& Sumbangan Pusat Kab.Pemalang

\begin{tabular}{|c|c|c|c|}
\hline Tahun & PAD (\%) & BHNP & $\begin{array}{c}\text { Sumbangan } \\
\text { Pusat }\end{array}$ \\
\hline 1 & 7.01 & 3.78 & 92.09 \\
\hline 2 & 7.69 & 4.75 & 86.71 \\
\hline 3 & 6.37 & 5.15 & 83.42 \\
\hline 4 & 5.67 & 5.58 & 82.97 \\
\hline Rata-rata & $\mathbf{6 . 6 9}$ & $\mathbf{4 . 8 2}$ & $\mathbf{8 6 . 3 0}$ \\
\hline
\end{tabular}




\section{c.Menghitung DDF 2 dengan membandingkan Rasio antara PAD ditambah BHPNP terhadap Pengeluaran Daerah}

Tabel 10. Rasio PAD ditambah BHPNP

\begin{tabular}{|c|c|c|c|}
\hline Tahun & Klaten & Pati & Pemalang \\
\hline 1 & 7.89 & 16.56 & 12.38 \\
\hline 2 & 8.45 & 17.66 & 14.01 \\
\hline 3 & 8.55 & 20.21 & 12.12 \\
\hline 4 & 11.53 & 17.81 & 11.96 \\
\hline Rata-rata & $\mathbf{9 . 1 1}$ & $\mathbf{1 8 . 0 6}$ & $\mathbf{1 2 . 6 2}$ \\
\hline
\end{tabular}

Untuk tolak ukur terakhir, yaitu DDF, hasil analisis data menunjukkan rasio-rasio DDF ketiga kabupaten masih jauh berada di angka satu (1). Rasio DDF yang pertama, yaitu perbandingan rata-rata antara PAD dengan total penerimaan daerah untuk Klaten sebesar 4,49\%, Pati sebesar 9,80\%, dan Pemalang sebesar 6,69\%. (2) Rasio DDF yang kedua, yaitu rata-rata perbandingan antara PAD ditambah BHPNP terhadap total pengeluaran daerah juga sangat rendah, untuk Klaten sebesar 9,11\%, Pati sebesar $18,06 \%$, dan Pemalang sebesar 12,62\%. Hal ini menunjukkan bahwa kemampuan keuangan pemerintah daerah Klaten, Pati dan Pemalang dalam membiayai urusan daerah dengan sumber keuangan sendiri masih sangat rendah. Akibatnya ketergantungan terhadap pemerintah pusat semakin tinggi.

\section{KESIMPULAN}

Dengan tidak terpenuhinya ketiga tolak ukur yang diterapkan pada pemerintah Kabupaten Klaten, Pati dan Pemalang terhadap standar kemampuan keuangan daerah dalam menghadapi otonomi daerah, dapat ditarik kesimpulan bahwa pemerintah Kabupaten Klaten, Pati dan Pemalang belum mampu atau belum layak dalam melaksanakan otonomi daerah dari sektor keuangan.

\section{SARAN}

1. Kapasitas fiskal seharusnya lebih di tingkatkan untuk memenuhi kebutuhan fiskal suatu daerah dengan cara lebih memperhatikan sektorsektor yang berpotensi (sektor basis) pada setiap kabupaten, yang mampu meningkatkan kemampuan keuangan daerah secara proporsional, sesuai dengan potensi yang dimilikinya.

2. Secara intensifikasi, pemerintah Kabupaten Klaten, Pati dan Pemalang seharusnya dapat mengidentifikasikan sumber-sumber penerimaan apa saja yang belum dimasukkan atau dikelompokkan.

3. Kinerja pengelolaan pemungutan pajak daerah dan Bagi Hasil seharusnya lebih ditingkatkan lagi guna meningkatkan penerimaan daerah

4. Seharusnya dalam alokasi pengeluaran APBD tidak mengedepankan kepentingan suatu kelompok atau golongan saja, tetapi harus benarbenar sesuai dengan kebutuhan dan tepat guna.

5. Untuk memperoleh kesimpulan yang lebih akurat mengenai porsi anggaran pembangunan yang dialokasikan ke sektor basis, maka penelitian selanjutnya perlu dilakukan dengan menggunakan APBD dengan periode yang lebih lama lagi, terutama sekarang banyak undang-undang dan peraturan pemerintah baru yang di buat dalam rangka peningkatan kinerja keuangan negara dan daerah, alangkah lebih baiknya jika ada penelitian mengenai perbedaan kinerja keuangan tiap daerah kabupaten sebelum dan sesudah terbitnya undang-undang atau peraturan pemerintah tersebut. 


\section{DAFTAR PUSTAKA}

Arsyad, Lincoln, 1999, "Pengantar Perencanaan dan Pertumbuhan Ekonomi Daerah", BPFE-UGM, Yogyakarta.

Bastian, Indra, 2001, “ Akuntansi Sektor Publik di Indonesia”, BPFE-UGM, Yogyakarta.

Baswir, Revrisond, 1999, “ Akuntansi Pemerintahan Indonesia.” BPFE, Yogyakarta.

Belkaoui, Ahmed, 1981, "Accounting Theory”, Harcourt Brace Jovanovich, Inc., New York.

Djolodara, Dimas, 2003, "Analisa Kemampuan Keuangan pada Kelima Daerah Tingkat II di DI.Yogyakarta dalam Menyambut Otonomi Daerah." UII, Yogyakarta.

Halim, Abdul, 2001, "Manajemen Keangan Daerah", Penerbit Bunga Rampai, Yogyakarta.

Kaho, Josef Riwu, Grafindo, 1997,"Prospek Otonomi Daerah di Negara Republik Indonesia”, PT.Raja Grafindo, Jakarta.

Jones, Rowan and Pendlebury, Maurice, 1996,"Public Sector Accounting”, Fourth Edition, Pitman Publishing, London.

Mardiasmo, 2002,"Akuntansi Sektor Publik", Andi, Yogyakarta.

Mardiasmo, 2002, "Otonomi Daerah sebagai Upaya Memperkokoh Basis Perekonomian Daerah." Jurnal Ekonomi Rakyat Thn.1- No.4 - Juni 2002

Mardiasmo, 2002, "Penanggulangan Kemiskinan di Jawa Tengah dalam Era Otonomi Daerah." Jurnal Ekonomi Rakyat Thn.1 - No.9 November 2002.

Memesah, D.J., 1995, "Sistem Administrasi Keuangan Daerah", Gramedia, Jakarta.

Republik Indonesia, 1999, " UndangUndang Republik Indonesi Nomor

22 Tahun 1999 Tentang "Pemerintahan Daerah."
Republik Indonesia, 1999, " UndangUndang Republik Indonesi Nomor 25 Tahun 1999 Tentang "Perimbangan Keuangan antara Pemerintahan Pusat dan Daerah." 
